\title{
Primær ciliedyskinesi
}

\author{
Primær ciliedyskinesi er en sjelden sykdom, men den gir symptomer \\ som ligner langt vanligere luftveissykdommer. Derfor stilles diagnosen \\ ofte sent, gjerne når luftveisskade allerede har oppstått. Hensikten med \\ denne artikkelen er å belyse tilstanden og hvilke diagnostiske metoder \\ som finnes. Artikkelen er basert på litteratursøk i PubMed og på forfat- \\ terens egen erfaring fra pasientbehandling og klinisk forskning.
}

Primær ciliedyskinesi (PCD) er en sjelden recessiv genetisk sykdom som rammer bevegelige cilier og fører til dårlig slimmobilisering og stagnasjon av sekret i øvre og nedre luftveier, kronisk rhinosinusitt, tilbakevendende mellomørebetennelse og etter hvert til utvikling av bronkiektasier. Rundt $50 \%$ av pasientene har situs inversus totalis (Kartageners syndrom) og ca. $12 \%$ heterotaksi (ubestemt situs, ofte assosiert med kompleks hjertefeil) (1). Omkring $50 \%$ av mennene er infertile.

Det finnes sykdommer som rammer ikkebevegelige cilier også, for eksempel retinitis pigmentosa, multicystisk nyresykdom og Bardet-Biedls syndrom (2). Det er en viss overlapping av funksjonen til disse to cilietypene, slik at det finnes bronkiektasier hos noen pasienter med multicystisk nyresykdom og retinitis pigmentosa hos noen få pasienter med primær ciliedyskinesi. Ciliopatier er fellesbetegnelsen på disse sykdommene.

\section{Forekomst}

Den estimerte prevalensen av primær ciliedyskinesi varierer fra 1:10 000 til 1:30 000. Den virkelige prevalensen er usikker, da sykdommen sannsynligvis er underdiagnostisert. I tillegg er det forskjellig prevalens i ulike etniske grupper. I en asiatisk befolkning i Storbritannia som i hovedsak besto av personer med pakistansk bakgrunn, fant man en estimert prevalens på $1: 2200$. Det er antatt at prevalensen er høyere i grupper der forekomsten av inngifte er høy (3).

Basert på disse tallene kan man forvente at det finnes minst 180 personer i Norge med sykdommen, men mindre enn 50 tilfeller er kjent.

\section{Klinisk presentasjon}

Minst $75 \%$ av nyfødte med primær ciliedyskinesi har symptomer ved fødselen, blant annet pneumoni, atelektase, nesetetthet eller respirasjonsbesvær med behov for supplerende oksygen i noen dager eller uker (4). Nesten alle utvikler kronisk våt hoste og får gjentatte nedre luftveisinfeksjoner. Imidler- tid stilles diagnosen sjelden hos spedbarn, siden slike symptomer er vanlige i denne alderen uten at det foreligger alvorlig underliggende sykdom (5).

Gjennomsnittlig alder ved diagnosetidspunktet er 5,8 år, hos barn med situs inversus er den 3,5 år. Bronkiektasier kan da allerede være etablert (6). Ofte forteller foreldrene at de ikke kan gå ut uten lommetørkle fordi barnets nese stadig renner og er tett. Flertallet av barna har hørselstap, i varierende grad, noe som skyldes væske i mellomøret, og de får gjentatte episoder med akutt otitt.

Omtrent en tredel av pasientene har et raskt progredierende sykdomsforløp, med tap av $10-37 \%$ av lungefunksjonen i median 9,5 år, og hos en tredel av dem som blir diagnostisert i førskolealderen, er lungefunksjonen under $80 \%$ av forventet ved første måling (7). Hos dem som blir diagnostisert sent, kan forsert ekspiratorisk volum $\mathrm{i}$ ett sekund $\left(\mathrm{FEV}_{1}\right)$ være så lavt som $35-50 \%$ av forventet (7). I enkelte tilfeller er det behov for lungetransplantasjon.

Tidligere ble det ansett som fordelaktig å få diagnosen i ung alder, ved at det kunne føre til stabilisering av lungefunksjonen (8). Senere studier har vist at lungefunksjonen hos noen pasienter vil svekkes på tross av tidlig diagnose og igangsatt behandling (7). Levetiden er antatt å være normal, men det finnes ikke longitudinelle studier som kan verifisere dette.

\section{Ciliefunksjon og genetikk}

På den apikale overflaten av hver epitelcelle i luftveiene finnes det omtrent 200 cilier som slår i et koordinert mønster med en frekvens på $8-14 \mathrm{~Hz}$ for å drive ut slim og inhalerte partikler. Hos pasienter med primær ciliedyskinesi har ciliene unormal slagfrekvens og et slagmønster som kan være statisk, kaotisk, sirkulært eller stivt, avhengig av de assosierte genmutasjonene (9). I sjeldne tilfeller kan ciliene mangle.

Ved hjelp av transmisjonselektronmikroskopi var Afzelius den første til å beskrive en primær ciliedefekt hos mennesker, karakterisert ved komplett mangel på dynein-

\author{
Suzanne Crowley \\ suzcro@ous-hf.no \\ Lunge-allergi-seksjonen \\ Barneklinikken \\ Oslo universitetssykehus, Rikshospitalet
}

\section{HOVEDBUDSKAP}

Kronisk våt hoste fra fødselen er vanlig hos pasienter med primær ciliedyskinesi. Hosten responderer ikke på antibiotikabehandling

Alder ved diagnosetidspunktet er ofte høy, og luftveisskade kan da allerede ha oppstått

Diagnostisering av primær ciliedyskinesi er vanskelig og krever spesialistkompetanse 
armer, som koordinerer ciliebevegeligheten (10). Transmisjonselektronmikroskopi var tidligere gullstandard for diagnostisering av sykdommen, og ved hjelp av denne teknikken har man kunnet identifisere av ytre eller kombinert ytre og indre dyneinarm-defekter hos de fleste pasientene (fig 1, fig 2) (11).

Isolerte indre dyneinarm-defekter er sannsynligvis forårsaket av en nylig gjennomgått virusinfeksjon, siden ny undersøkelse av disse pasientene flere måneder senere viser regenerering hos de fleste. Det er derfor viktig at pasienter med isolerte indre dyneinarmdefekter ikke får diagnosen primær ciliedyskinesi uten at det foreligger flere funn som understøtter dette.

Det finnes også andre ultrastrukturelle defekter, men hos $10-30 \%$ av pasientene med sykdommen finnes det ikke slike (12). Disse pasientene vil likevel vise tegn på ciliedyskinesi ved lysmikroskopisk vurdering av cilieslag, -frekvens og slagmønster. Bruk av transmisjonselektronmikroskopi som eneste diagnostiske test for primær ciliedyskinesi er assosiert med både over- og underdiagnostisering (12). Riktig behandling av prøver til undersøkelsen samt kunnskap om normal variasjon av cilieultrastruktur er avgjørende for riktig fortolkning av mikrografene.

I motsetning til den sparsomme publiserte kliniske forskningen om sykdommen har det vært en eksplosjon i forskningen på tilstandens genetikk, særlig de siste fem årene. Det er nå identifisert mutasjoner i mer enn 30 gener. Mutasjonene forårsaker forskjellige misdannelser i ciliestruktur og -funksjon. Disse står for to tredeler av antallet kjente tilfeller av primær ciliedyskinesi.

Ytre dyneinarm-defekter finnes hos ca. $60 \%$ av pasientene, og hos disse er ca. $60 \%$ av tilfellene forårsaket av mutasjoner i to gener: DNAI1 og DNAH5. Mutasjoner i et annet gen, $D N A H 11$, finnes hos ca. $12 \%$ av pasientene med sykdommen og er assosiert med en ultrastrukturell defekt som er synlig ved bruk av elektrontomografi som lager tredimensjonale ciliemodeller med høy oppløsning, men de er ikke synlige ved vanlig transmisjonselektronmikroskopi (13).

\section{Screening og diagnose}

Siden symptomene på primær ciliedyskinesi er felles for mange lungesykdommer, særlig gjelder det sykdommer hos førskolebarn (5), kreves det spesiell årvåkenhet og kunnskap hos behandlende leger for å stille diagnosen. Måling av nasal nitrogenmonoksid (nNO) representerer et viktig fremskritt i screeningen for sykdommen og er et sensitivt og spesifikt verktøy, men av tekniske årsaker mindre spesifikk for barn under fem år.

Nesten alle pasienter med primær ciliedyskinesi har nNO-verdi på under 250 parts

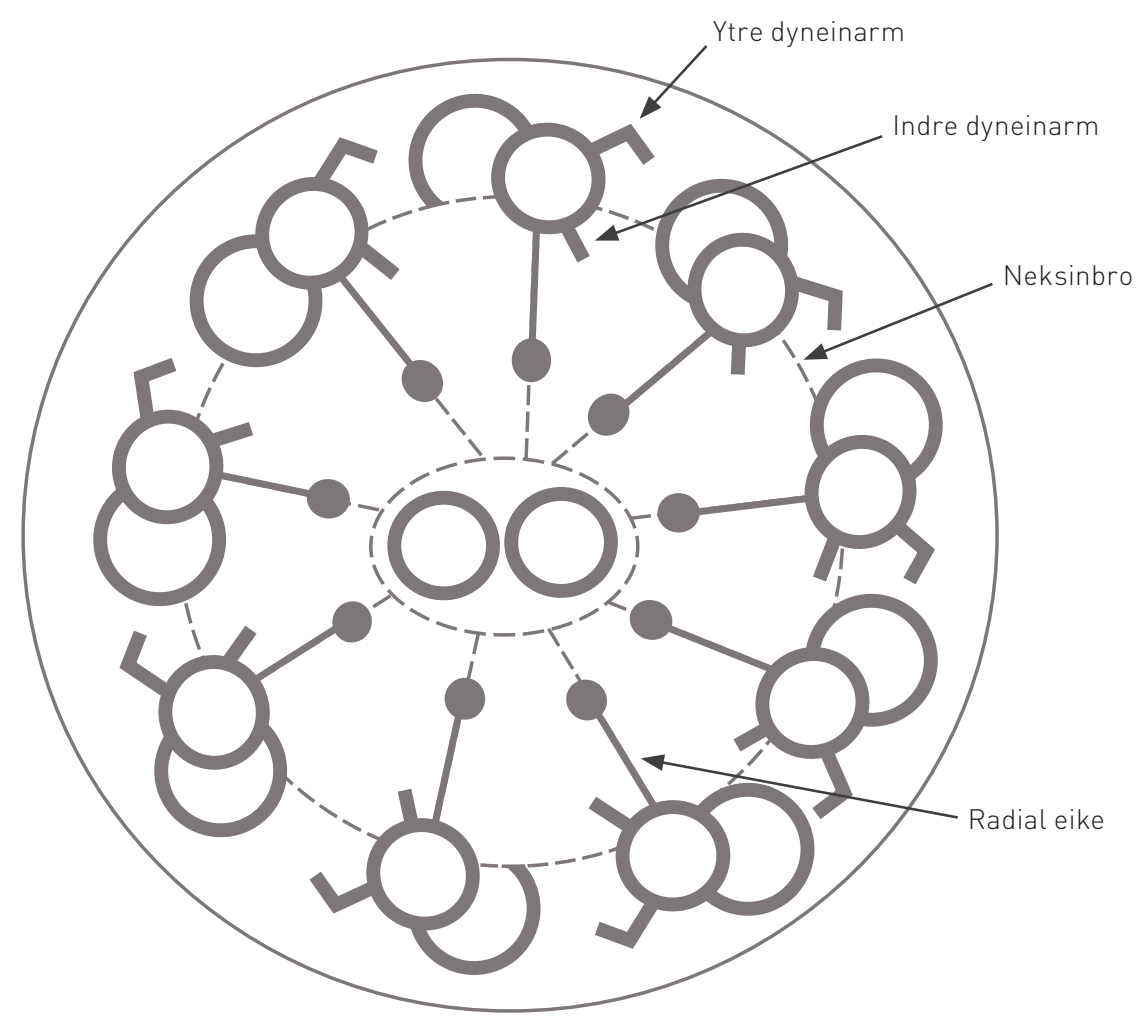

Figur 1 Skjematisk tegning av tverrsnitt av cilie, etter Leigh og medarbeidere (11), med tillatelse fra Nature Publishing Group per billion (ppb), hos de fleste er den under $100 \mathrm{ppb}$. Årsaken til lav nNO-verdi hos disse pasientene er ukjent. Standarder for måling av nNO-verdi uttrykt som produksjonsrate er blitt publisert (14), og grenseverdier under $77 \mathrm{nl} / \mathrm{min}$ er valide i forskjellige sentre, analysatorer og populasjoner. Likevel er dette ikke en absolutt verdi som kan utelukke tilstanden. Derimot er mangelen på typiske kliniske tegn samt normal nNO-verdi sterke indikatorer på en annen diagnose enn primær ciliedyskinesi. Det er anbefalt at $\mathrm{nNO}$-screening gjøres ved spesialiserte sentre som har erfaring med pasienter med primær ciliedyskinesi (14).

Pasienter som har lav nNO-verdi eller pasienter der det finnes sterk klinisk mistanke om sykdommen, bør henvises til et spesialistsenter for å få diagnosen bekreftet (15). I Norge gjøres dette ved Oslo universitetssykehus, Rikshospitalet, som nylig er blitt godkjent som kompetansetjeneste for primær ciliedyskinesi.

Klinisk evaluering, inkludert nNO-måling, kan etterfølges av børstebiopsi av concha nasalis inferior for å få en prøve av cilierte epitelceller. Disse kan vurderes ved bruk av høyhastighetsvideomikroskopi for å bestemme cilieslagfrekvens og -slagmønster, men få sentre i Europa (og ingen $\mathrm{i}$ Norge) kan tilby denne undersøkelsen. Uavhengig av om det kan utføres funksjonell

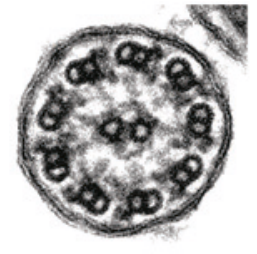

Normal

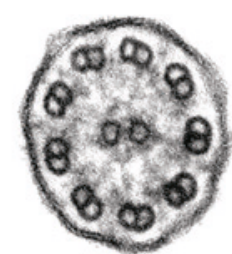

Manglende ytre og indre dyneinarmer

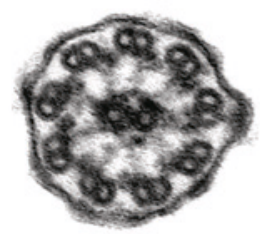

Manglende ytre dyneinarmer

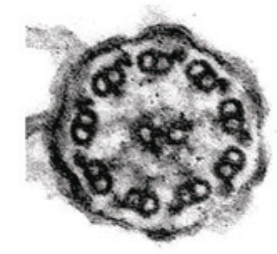

$0,15 \mu \mathrm{m}$

Manglende indre dyneinarmer
Figur 2 Bilder fra transmisjonselektronmikroskopi, etter Leigh og medarbeidere (11). Gjengitt med tillatelse fra Nature Publishing Group 
vurdering av cilier eller ikke, er neste steg $\mathrm{i}$ diagnostiseringen analyse av cilieultrastruktur ved bruk av elektronmikroskopi.

I Norge gjøres de fleste transmisjonselektronmikroskopiske undersøkelsene ved Oslo universitetssykehus, Rikshospitalet. Metodene varierer, men det er anbefalt at minst 100 cilietverrsnitt per pasient undersøkes for dyneinarmdefekter, en prosess som krever både spesialistkompetanse og mye tid (16). Epitelceller kan også dyrkes for å lette regenereringen av cilier når de er skadet av inflammasjon, for dermed å spare pasienten for ubehaget som følger med en ny børstebiopsi. Dette tilbudet finnes imidlertid kun ved en håndfull sentre i Europa.

Ciliedefekter kan også påvises ved bruk av immunfluorescerende antistoffer rettet mot spesifikke strukturelle cilieproteiner. Denne teknikken anvendes mest som forskningsverktøy, men kan brukes til å vise manglende proteiner når transmisjonselektronmikroskopien er normal. Børstebiopsi unngås dersom pasienten har hatt en virusinfeksjon i løpet av de siste fire uker på grunn av virusindusert cilieskade. Hos pasienter med typiske symptomer, lav nNO-verdi og normal cilieultrastruktur kan genetisk undersøkelse for kjente mutasjoner bekrefte diagnosen, særlig gjelder det pasienter som har mutasjoner i DNAH11-genet.

\section{Behandling}

Primær ciliedyskinesi behandles som cystisk fibrose - selv om det ikke finnes sikker kunnskap om at dette er effektivt.

Slimmobilisering er svært viktig. Fordi ciliene ikke fungerer, er pasientene avhengig av fysioterapi i form av pusteøvelser, bruk av PEP-maske, hosting og særlig fysisk aktivitet for å få opp slim. Anekdotisk får noen pasienter god effekt av inhalasjoner med $7 \%$ $\mathrm{NaCl}$ både når det gjelder slimmobilisering og lungefunksjon, men dette er ikke undersøkt i kliniske studier. Inhalasjonssteroider er uten effekt og bør unngås dersom pasienten ikke har astma som tilleggsdiagnose.

Tidlig behandling av virale luftveisinfeksjoner med antibiotika i minst ti dager anbefales, siden de fleste pasienter har kronisk bakteriell kolonisering som forverres under pågående viral infeksjon. Neseskylling med $0,9 \% \mathrm{NaCl}$ eller sterkere $\mathrm{NaCl}$-oppløsning anbefales, ved hjelp av dråper, nesehorn eller neseforstøverapparat.

Behandlingen av hørselstap hos disse pasientene er kontroversiell. Bruk av trommehinnedren er assosiert med opptil $50 \%$ forekomst av permanent perforasjon og vedvarende lekkasje - uten at det nødvendigvis blir noen forbedring av hørselen. Drensinnlegging er derfor ikke ansett som hensiktsmessig for de fleste pasientene, men bruk av høreapparat anbefales (17).

\section{Hvem bør henvises til screening?}

Respirasjonsbesvær, pneumoni eller atelektase og nesetetthet hos et barn født til termin bør føre til henvisning for screening av primær ciliedyskinesi. Likedeles bør barn med situs inversus henvises til screening, siden omtrent $25 \%$ av dem må forventes å ha sykdommen (18). Vedvarende daglig våt hoste fra spedbarnsalder, uforklarlige bronkieektasier, tilbakevendende bihulebetennelse, hørselstap som skyldes væske i mellomøret og kompleks hjertefeil med heterotaksi øker sannsynligheten for tilstanden.

Hos menn er infertilitet på grunn av nedsatt spermiebevegelighet og hos kvinner svangerskap utenfor livmoren (19) relevant informasjon som kan føre til mistanke om sykdommen. For øvrig er ikke høy voksen alder til hinder for at man kan bli diagnostisert med primær ciliedyskinesi. Diagnosen er blitt stilt hos eldre mennesker som hele livet har vært plaget av symptomer fra luftveiene samt eventuelt hørselstap og infertilitet.

\section{Diskusjon}

Primær ciliedyskinesi er en sjelden sykdom som særlig rammer luftveiene. Diagnosen stilles ofte sent, og luftveisskade kan da allerede ha oppstått.

For å bøte på mangelen på klinisk forskning om sykdommen er det etablert et europeisk konsortium (BESTCILIA) og et samarbeid (Cooperation in Science and Technology) hvor Norge er representert. Gjennom dette fellesskapet kan internasjonalt forskningssamarbeid om sykdommen ivaretas og utvikles.

Diagnostiske tjenester bør av kapasitetsog kompetansemessige grunner være sentralisert og utvikles i henhold til anerkjente internasjonale retningslinjer (15). Jeg vil ta til orde for å utvikle et system med delt ansvar mellom kompetansesenter og lokalsykehus for pasientoppfølging, tilsvarende det som gjøres ved cystisk fibrose. Dermed får man samlet den diagnostiske kompetansen og samtidig lagt til rette for formidling av kunnskap og erfaring til samarbeidspartnere ved andre behandlingsinstitusjoner. Etter min mening bør det også utvikles et nasjonalt register for sjeldne lungesykdommer, deri innbefattet primær ciliedyskinesi, slik at kunnskapen om disse uvanlige tilstandene kan bli større.

\section{Suzanne Crowley (f. 1956)}

er dr.med. og spesialist i pediatrisk pulmonologi fra England. Hun er overlege og leder for Den norske legeforenings barnelungeinteressegruppe.

Forfatter har fylt ut ICMJE-skjemaet og oppgir ingen interessekonflikter.
Litteratur

1. Shapiro AJ, Davis SD, Ferkol T et al Laterality defects other than situs inversus totalis in primary ciliary dyskinesia: insights into situs ambiguus and heterotaxy. Chest 2014; 146: 1176-86.

2. Horani A, Brody SL, Ferkol TW. Picking up speed advances in the genetics of primary ciliary dyskinesia. Pediatr Res 2014; 75: 158-64.

3. O'Callaghan C, Chetcuti P, Moya E. High prevalence of primary ciliary dyskinesia in a British Asian population. Arch Dis Child 2010; 95: $51-2$.

4. Mullowney T, Manson D, Kim R et al. Primary ciliary dyskinesia and neonatal respiratory distress. Pediatrics 2014; 134: 1160-6.

5. Bush A, Chodhari R, Collins N et al. Primary ciliary dyskinesia: current state of the art. Arch Dis Child 2007: 92: 1136-40.

6. Kuehni CE, Frischer T, Strippoli M-PF et al. Factors influencing age at diagnosis of primary ciliary dyskinesia in European children. Eur Respir J 2010; 36: 1248-58.

7. Marthin JK, Petersen N, Skovgaard LT et al. Lung function in patients with primary ciliary dyskinesia: a cross-sectional and 3-decade longitudinal study. Am J Respir Crit Care Med 2010; 181: 1262-8.

8. Ellerman A, Bisgaard H. Longitudinal study of lung function in a cohort of primary ciliary dyskinesia. Eur Respir J 1997; 10: 2376-9

9. Raidt J, Wallmeier J, Hjeij R et al. Ciliary beat pattern and frequency in genetic variants of primary ciliary dyskinesia. Eur Respir J 2014: 44: 1579-88.

10. Afzelius BA. A human syndrome caused by immotile cilia. Science 1976; 193: 317-9

11. Leigh MW, Pittman JE, Carson JL et al. Clinical and genetic aspects of primary ciliary dyskinesia/ Kartagener syndrome. Genet Med 2009; 11 473-87.

12. Leigh MW, O'Callaghan C, Knowles MR. The challenges of diagnosing primary ciliary dyskinesia. Proc Am Thorac Soc 2011; 8: 434-7.

13. Kwan R, Burgoyne T, Dixon M et al. Electron tomography detects ultrastructural abnormalities in patients with PCD due to DNAH11 defect. Thorax 2014: 69 (suppl 2): A48-9

14. Leigh MW, Hazucha MJ, Chawla KK et al. Standardizing nasal nitric oxide measurement as a test for primary ciliary dyskinesia. Ann Am Thorac Soc 2013: 10: 574-81

15. Strippoli M-PF. Frischer T, Barbato A et al. Management of primary ciliary dyskinesia in European children: recommendations and clinical practice. Eur Respir J 2012; 39: 1482-91.

16. Shoemark A, Dixon M, Corrin B et al. Twenty-year review of quantitative transmission electron microscopy for the diagnosis of primary ciliary dyskinesia. J Clin Pathol 2012; 65: 267-71.

17. Prulière-Escabasse $V$, Coste $A$, Chauvin $P$ et al. Otologic features in children with primary ciliary dyskinesia. Arch Otolaryngol Head Neck Surg 2010; 136: 1121-6.

18. Katsuhara K, Kawamoto S, Wakabayashi T et al. Situs inversus totalis and Kartagener's syndrome in a Japanese population. Chest 1972. 61. 56-61.

19. McComb P, Langley L, Villalon M et al. The oviduc tal cilia and Kartagener's syndrome. Fertil Steril 1986; 46: 412-6.

Mottatt 23.3. 2015, første revisjon innsendt 15.7 2015, godkjent 10.12. 2015. Redaktør: Liv-Ellen Vangsnes. 